\title{
ISOLASI DAN KARAKTERISTIK BAKTERI DALAM LAMUN Enhalus acroides DIPERAIRAN PASARWAJO BUTON
}

\author{
Sabaniah Indjar Gama* \\ Jurusan Kimia, Fakultas Farmasi Universitas Mulawarman \\ Kampus UNMUL Gunung Kelua, Samarinda \\ *Kontak : Sndjargama@yahoo.com
}

\begin{abstract}
ABSTRAK
Lamun Enhalus acroides merupakan sumber makanan penting bagi banyak organisme diperairan, selain itu juga lamun memberikan habitat bagi berbagai makorganisme dan mikroorganisme laut, salah satunya adalah bakteri karena lamun menyediakan tempat hidup serta nutrisi pada bakteri. Penelitian ini bertujuan untuk mengisolasi bakteri yang berada pada lamun Enhalus acoroides, menentukan laju pertumbuhan bakteri yang bersimbion pada lamun dan menentukan jenis bakteri yang diisolasi pada lamun. Adapun tahapan-tahapan adalah isolasi, identifikasi bakteri dengan uji fisiologis (pewarnaan), uji biokimia. Berdasarkan hasil penelitian bahwasanya bakteri yang bersimbion pada lamun Enhalus acoroides tumbuh pada suhu maksimum $27^{\circ} \mathrm{C}$ pada pengenceran $10^{-2}$. Sedangkan penentuan karakter morfologi dan pewarnaan gram bakteri simbion, dilakukan berdasarkan Microbiology Laboratory Manual dan menunjukkan bahwa morfologi sel bakteri yang berada pada lamun yaitu basill (batang), hasil perwarnaan gram pada bakteri lamun diperoleh gram negatif, begitu juga uji biokimia dan dapat bahwa bakteri yang bersimbion pada lamun adalah Klebsiella sp.
\end{abstract}

Kata Kunci : Bakteri simbiont, Pasarwajo Buton, Enhalus acoroides.

\begin{abstract}
Seagrass enhalus acroides is important well food. For marine organisms, besides that, seagrass also. Provide place for macroorganisms and microorganisms in marine, one of them for bacterium. Seagrass provide good place and nutrients for bacteria. This study aims to isolate the bacteria that are in the seagrass Enhalus acoroides, determining the rate growth of bacterial Symbionts on seagrass and determine the type of bacteria that is isolated on seagrass. stage of this study are isolation, identification of bacteria with physiological test (staining), and biochemistry test. the result show that bacterial symbionts on seagrass Enhalus acoroides grow at $27^{\circ} \mathrm{C}$ as maximum temperature on $10^{-2}$ dilution. While the determination of morphological characters and gram bacterial symbionts, conducted manually by Microbiology Laboratory and show that the morphology of bacterial cells that are in the seagrass is basill (rod), the gram colouring on seagrass acquired gram-negative, as well as biochemical tests and the bacterial symbionts on seagrass is Klebsiella $s p$.
\end{abstract}

Kata kunci : bacterial symbionts, Pasarwajo Buton, Enhalus acoroides. 


\title{
PENDAHULUAN
}

Lamun (seagrass) merupakan kelompok tumbuhan berbiji tertutup (Angiospermae) dan berkeping tunggal (Monokotil) yang mampu hidup secara permanen di bawah permukaan air laut. Lamun merupakan satu-satunya tumbuhan berbunga (Angiospermae) yang memiliki rhizoma, daun, dan akar sejati yang hidup terendam di dalam laut beradaptasi secara penuh di perairan yang salinitasnya cukup tinggi atau hidup terbenam di dalam air, beberapa ahli juga mendefinisikan lamun sebagai tumbuhan air berbunga, hidup di dalam air laut, berpembuluh, berdaun, berimpang, berakar, serta berbiak dengan biji dan tunas (Fitriana, 2007).

Dalam ekosistem lamun, rantai makanan tersusun dari tingkat-tingkat trofik yang mencakup proses dan pengangkutan detritus organik dari ekosistem lamun ke konsumen yang agak rumit. Sumber bahan organik berasal dari produk lamun itu sendiri, di samping tambahan dari epifit dan alga makrobentos, fitoplankton dan tanaman darat. Zat organik dimakan fauna melalui perumputan (grazing) atau pemanfaatan detritus (Romimohtarto dan Juwana, 2009). Salah satu factor ketertarikan organisme untuk menetap di lingkungan tersebut adalah padang lamun tergolong habitat yang produktif, sehingga mampu menyediakan makanan untuk kelangsungan hidup organisme yang berasosiasi.

Salah satu mikroorganisme yang ditemukan dalam jumlah yang melimpah ditemukan di padang lamun adalah bakteri. Bakteri merupakan komponen penting dalam proses mineralisasi pada ekosistem padang lamun. Lamun yang telah mati didekomposisi oleh bakteri, hasilnya berupa detritus sebagai makanan dari hewan-hewan laut antara lain cacing, teripang, krustase, anemon dan, ascidian, selain itu hasil degradasi organisme mati dapat menghasilkan nitrat dan fosfat yang dapat digunakan oleh tanaman lamun dan plankton. Bakteri selain berada di sekitar lamun juga berasosiasi dengan lamun, bakteri tersebut hidup pada helai daun dan cabang-cabang rimpang yang tegak. Beberapa bakteri asosiasi lamun memberikan konstribusi untuk pertahanan inangnya dengan cara mengeksresi antibiotik dan substansi bioaktif lainnya (Massinai, 2013). Adapun tujuan penelitian ini adalah untuk mengisolasi bakteri yang berada pada lamun Enhalus acoroides, menentukan laju pertumbuhan bakteri yang bersimbion pada lamun dan menentukan jenis bakteri yang diisolasi pada lamun.

\section{METODE PENELITIAN}

\section{Bahan}

Bahan yang digunakan adalah medium nutrien agar (NA), $\mathrm{NaCl}$ fisiologis, pewarnaan Gram digunakan larutan Safranin, Lugol Iodine, alkohol 96\% dan kristal violet, Uji biokimia menggunakan TSA, $\mathrm{H}_{2} \mathrm{~S}$, media TSI, media SIM, reagen kovac, glukosa, sukrosa, laktosa, regen metil red, medium Simmon's Citrate, Urea Broth, mediumMcConky, mediumTSIA, medium MR-VP

\begin{abstract}
Alat
Alat yang digunakan adalah autoclave, cawan petri, mikropipet, ose, inkubator, neraca analitik, kain saring, tabung reaksi, erlenmeyer, beaker glass, plastik clening warp, aluminium foil.
\end{abstract}

\section{Prosedur}

\section{Persiapan sampel}

Sampel yang diperoleh dicuci bersih dengan aquades, kemudian disimpan kedalam pelastik yang berisi air laut steril dan gliserol $10 \%$ 


\section{Penentuan Pengenceran}

Sebanyak 15 gram Lamun dicuci dengan air laut steril, kemudian digerus dengan penambahan $\mathrm{NaCl}$ fisiologis $0,9 \%$, setelah itu dibuat seri pengenceran dari $10^{-1}$ sampai dengan $10^{-8}$, selanjutnya dipipet sebanyak $0,05 \mathrm{~mL}$ sampel dimasukan kedalam $10-15 \mathrm{~mL}$ NA (metode tuang) setelah itu diinkubasi pada suhu kamar yakni suhu $27^{\circ} \mathrm{C}$.

\section{Penentuan laju pertumbuhan maksimum}

Sebanyak 15 gram Lamun dicuci dengan air laut steril, kemudian digerus dengan penambahan $\mathrm{NaCl}$ fisiologis $0,9 \%$, setelah itu dibuat seri pengenceran dari $10^{-1}$ sampai dengan $10^{-3}$, selanjutnya dipipet sebanyak $0,05 \mathrm{~mL}$ sampel dimasukan kedalam $10-15 \mathrm{~mL}$ NA (metode tuang) setelah itu diinkubasi pada suhu kamar yakni dengan waktu inkubasi 1 x 24 jam, 2 x 24 jam, 3 x 24 jam, 4 x 24 jam dan 5 x 24 jam.

\section{Isolasi dan Identifikasi Bakteri}

Isolat bakteri dengan pengenceran yang telah ditentukan ditumbuhkan dan dimurnikan dengan metode gores. Isolat murni yang diperoleh kemudian diidentifikasi. Identifikasi yang dilakukan meliputi pewarnaan gram, pengamatan mikroskopis, pengujian biokimia (TSIA, SIM, uji fermentasi gula-gula, sitrat, urea, VP-MR).

\section{HASIL DAN PEMBAHASAN}

\section{Penentuan Pengenceran}

Penentuan pengenceran, pengamatan pertumbuhan bakteri simbion lamun Enhalus acoroides dilakukan dengan cara menumbuhkan pada media nutrien agar dengan beberapa variasi pengenceran yakni $10^{-1}$ sampai dengan $10^{-8}$. bakteri yang bersimbion pada lamun, berada pada pengenceran $10^{-1}$ sampai dengan $10^{-3}$ yang mana mengikuti aturan perhitungan jumlah koloni bakteri dan mengikuti syarat (SPC) yakni pertumbuhan koloni tidak boleh lebih kecil dari 30 dan lebih besar dari 300 (Adriani, 2012).

\begin{tabular}{cc}
\multicolumn{2}{c}{ Tabel 1. Pertumbuhan Koloni } \\
\hline Pengenceran & Jumlah koloni \\
\hline $10^{-1}$ & 288 \\
$10^{-2}$ & 124 \\
$10^{-3}$ & 35 \\
$10^{-4}$ & 24 \\
$10^{-5}$ & 25 \\
$10^{-6}$ & 20 \\
$10^{-7}$ & 3 \\
$10^{-8}$ & 1 \\
\hline
\end{tabular}

Berdasarkan data pada Tabel 1 dan syarat perhitungan koloni, diperoleh bahwa pengenceran yang sesuai untuk bakteri simbion dalam lamun adalah pengenceran $10^{-2}$

\section{Penentuan Laju Pertumbuhan Bakteri}

Pada penelitian ini dilakukan pengamatan penentuan laju pertumbuhan bakteri dimana penentuan waktu inkubasi dilakukan terhadap isolate yang ditumbuhkan pada media nutrient agar sesuai dengan tingkat pengenceran yakni $10^{-2}$. Bakteri ditumbuhkan dengan waktu inkubasi 1 x 24 jam, 2 x 24 jam, 3 x 24 jam, 4 x 24 jam dan 5 x 24 jam, 
dimana waktu inkuasi yang sesuai untuk bakteri didasarkan pada pertumbuhan maksimum bakteri berdasarkan dari peningkatan angka pertumbuhan bakteri ( adriani, 2012)

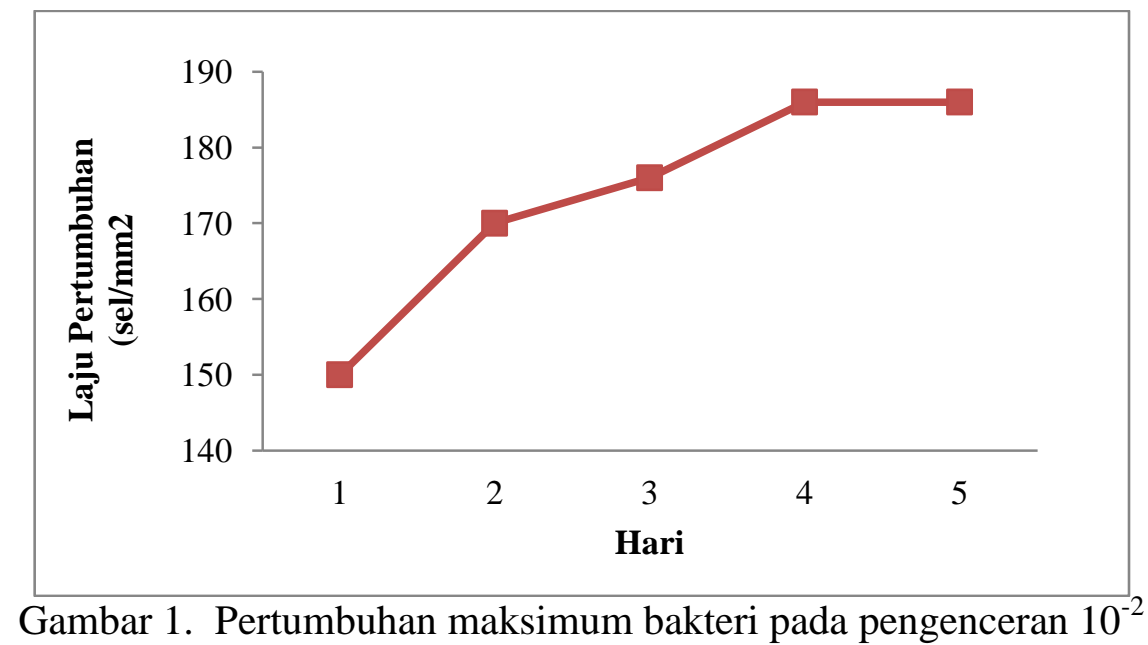

\section{Isolasi dan Identifikasi bakteri}

Tahap identifikasi bakteri simbion Enhalus acoroides diawali dengan isolasi dan identifikasi. Berdasarkan hasil identifikasi secara fisiologi diperoleh bahwa bakteri yang bersimbion pada lamun Enhalus acoroides pada pengenceran $10^{-2}$ berasal dari golongan gram negatif berbentuk batang (basill)yakni pada uji sapranil/steppuksil alkali yakni perwarnaan zat pada bakteri, prinsip dari uji sapranil yakni memberikan warna pada bakteri, jika dia Gram positif, bakteri menangkap zat sapranil dengan memberikan warna biru keunguan. Jika Gram negatif, bakteri menangkap zat sapranil dengan memberikan warna merah, dapat dilihat pada gambar 2 .

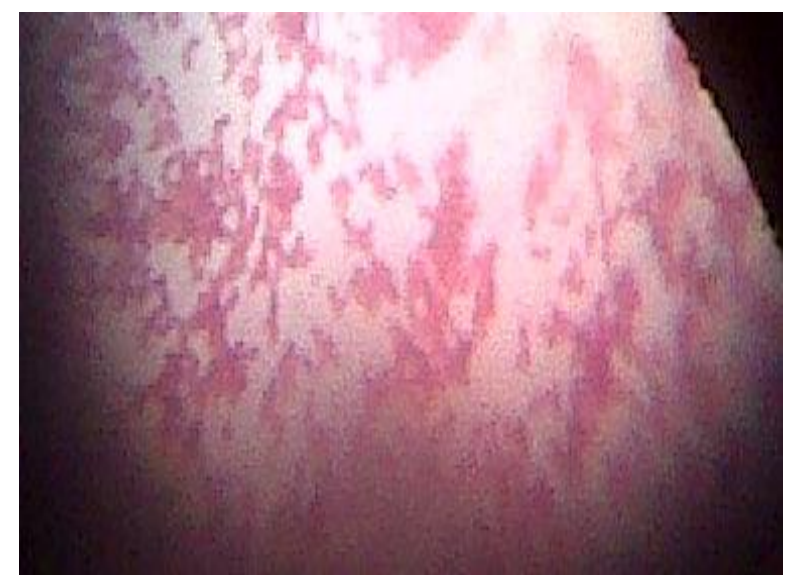

Gambar 2. Bakteri Gram negatif

Hasil uji biokimia pada bakteri lamun Enhalus acoroides yang ditumbuhkan ada pada tabel 2 . 
Tabel 2. Uji Biokimia pada simbion Lamun

\begin{tabular}{ccc}
\hline \multicolumn{2}{c}{ Pengujian } & Hasil \\
\hline TSIA & Slant & Asam \\
& Buth & Asam \\
& $\mathrm{H}_{2} \mathrm{~S}$ & - \\
SIM & Gas & + \\
& Indol & - \\
& Motil & - \\
MRP & $\mathrm{H}_{2} \mathrm{~S}$ & - \\
& $\mathrm{MR}$ & + \\
Sitrat & $\mathrm{VP}$ & + \\
Urea & & + \\
Glukosa & & + \\
Laktosa & & + \\
Sukrosa & & + \\
Mamitol & & + \\
& & + \\
\hline
\end{tabular}

Berdasarkan pada hasil uji biokimia diatas untuk uji Triple Sugar Iron (TSIA) yaitu asam/asam bewarna kuning pada bagian pangkal dan miring pada media TSIA hal ini menandakan bahwa bakteri memfermentasi 3 jenis karbohidrat yakni laktosa, maltosa dan sukrosa. Untuk ctas dapat terdeteksi gas dengan retakan pada media TSIA, akan tetapi tidak dihasilkannya $\mathrm{H}_{2} \mathrm{~S}$ pada media tersebut.

Uji SIM (sulfid indol multilinti) negatif yakni pembentukan $\mathrm{H}_{2} \mathrm{~S}$, reaksi indol dan motail pergerakan ditandai dengan tidak adanya endapan berwarna hitam. Media SIM adalah perbenihan semi solid yang dapat digunakan untuk mengetahui pembentukan $\mathrm{H}_{2} \mathrm{~S}$, indol dan motility dari bakteri. Bila positif menghasilkan warna merah sedangkan apabila negatif menghasilkan warna kuning. Berdasarkan uji indol diperoleh hasil negatif, hal ini menyatakan bahwa bakteri ini tidak hanya membentuk indol dari triptofan sebagai sumber karbon yang dapat diketahui dengan menambahkan larutan kovacs.

Uji MRVP digunakan untuk mendeteksi produksi asam kuat selama proses fermentasi glukosa. Pembentukan asam pada fermentasi glukosa memberikan warna merah dengan indikator metil merah. Voges-Prokauer merupakan uji untuk menentukan organisme yang memproduksi dan mengelola asam dan fermentasi glukosa, memperlihatkan kemampuan sistem buffer dan menentukan bakteri yang menghasilkan produk netral (asetil metal karbinol atau aseton) dari hasil fermentasi glukosa berdasarkan pada uji MRVP, diperoleh hasil positif dimana untuk uji MR menggunakan metil Red, dan positif untuk VP menggunakan regen alfa naftol 5\% dan $\mathrm{KOH} 40 \%$.

Uji karbohidrat (glukosa, sukrosa, laktosa dan maltosa) positif artinya bakteri membentuk asam dari fermentasi glukosa, sukrosa, laktosa dan maltosa. Uji sitrat, dimana pada uji ini bakteri diinokulasi pada medium simon sitrat Jika hasil positif terjadi perubahan warna indikator dari hijau menjadi biru yang bermakna pertumbuhan bakteri pada medium sitrat menghasilkan keadaan alkalis dan bakteri telah menggunakan sitrat, berdasarkan pada uji tersebut, diperoleh hasil positif.

Pada uji motilitas negatif dimana organisme non-motil hanya tumbuh pada garis inokulum. Setelah diidentifikasi bakteri yang memuat ciri-ciri spesies bakteri, diketahui bahwa bakteri lamun Enhalus acoroides yang ditumbuhkan adalah klebsiella sp (Gani, A. 2008). Adanya bakteri yang bersimbion pada lamun Enhalus acoroides karena, lamun 
mengandung karbohidrat dan bakteri klebsiella $s p$ menggunakan karbohidrat tersebut untuk proses metabolisme.

\section{KESIMPULAN}

Berdasarkan penelitian yang diperoleh bahwasanya bakteri yang diisolasi pada lamun Enhalus acoroides adalah Klebsiellla $s p$ yang merupakan bakteri gram negatif dengan morfologi bakteri basill (batang).

\section{Ucapan Terima Kasih}

Ucapan terima kasih disampaikan pada Program Pascasarjana Universitas Hasanuddin Makassar dan Universitas Mulawarman yang telah memberikan beasiswa untuk kelancaran penelitian.

\section{Daftar Pustaka}

1. Adriani, Alfian Noor, Abdul Rauf Patong, Maming. 2012. Analisis Kadar Logam Cu Dalam Bakteri Simbion Pada Spons Callyspongia sp. Jurnal marine acta 13 (2).

2. Brockman, F. J., Denovan, B., Hicks, R. J dan Fredicson, J. K. 1989. Isolation and characterization of quinoline degrading bacteria from subsurface sedimen. Appl. and Envinronm. Microbiology. Volume 59(1) : 340-343

3. Fenchel, T. 2001. Microorganisms (Microbes), Role Of: Encyclopedia of Biodiversity 4 : 207-219.

4. Gani, A. 2008. Metode bakteorologi diagnostik. BBLK : Makassar

5. Massinai, A, Abdul Haris, Eka Lisdayanti, dan Benny Audy Gosary. 2013 . Lamun Pulau Bonebatang, Kepulauan Spermonde Dan Bakteri Asosiasinya, Fakultas perikanan dan kelautan Universitas Hasanuddin, Makassar.

6. Lay, B. W. 1994. Analisis mikroba di laboratorium. Jakarta: PT. Raja Grafindo Persada.

7. Ogensky, E. L. and Umbreit W. W. 1959. An inroduction to Bacterial Physiology.2nd Ed. W. H. Freman and Company, san Franscisco and London: 117134.

8. Pelczar, M. J., Chan, E. C. S. 1986. Dasar-Dasar Mikrobiologi. Jilid I. Terjemahan Ratna Siri Hadioetomo. UI Press, Jakarta.

9. Ravikumar, S., Thajuddin N., Suganthi P., Jacob S and Vinodkumar T. 2010. Bioactive Potential of seagrass bacteria against Human bacterial Pathogens. Journal of Environmental Biology. 31 (3) : 387-389.

10. Rumiantin R.O. 2010. Kandungan Fenol, Komponen Fitokimia dan Aktivitas Antioksidan Lamun Enhalus acoroides [Skripsi]. Fakultas Perikanan dan Ilmu Kelautan, Institut Pertanian Bogor. Bogor. 